\title{
ULOGA ANKSIOZNOSTI U RELACIJI IZMEĐU POTREBE ZA ZAOKRUŽENOŠĆU I PARANOIDNOSTI ${ }^{1}$
}

\author{
Dragana Gogić́ ${ }^{2}$ Veljko Jovanović, Zdenka Novović \\ Filozofski fakultet, Odsek za psihologiju, Novi Sad
}

Cilj ovog rada je da se utvrdi uloga anksioznosti u relaciji izmedu paranoidnosti i pojedinačnih dimenzija potrebe za zaokruženošću (need for closure - NFC). Uzorak su činili 170 studenata Novosadskog univerziteta koj su ispunili upitnik NFCS, kao meru potrebe za zaokruženošću, PS skalu paranoidnosti i STAI-T, kao meru anksioznosti. Na osnovu prosečnog skora na Skali paranoidnosti uzorak je podeljen u dve grupe: grupa visoko paranoidnih $(N=75)$ i nisko paranoidnih ispitanika ( $N=95)$. Analizom glavnih komponenti, u prostoru merenja upitnika NFCS izolovano je pet Varimax dimenzija koje su interpretirane kao: Netolerancija nepredvidivosti, Potreba za redom i strukturom, Potreba za kontrolom i rutinom, Odlučnost i Otvorenost - fleksibilnost. Primenjene su MANOVA i MANCOVA, kako bi se utvrdila povezanost izolovanih dimenzija NFC sa paranoidnošću uz kontrolu anksioznosti. Analize su pokazale da jedna od NFC dimenzija, Potreba za redom i strukturom, nije bila značajno povezana niti sa jednim prediktorom, a samo jedan aspekt potrebe za zaokruženošću - Potreba za kontrolom i rutinom, bio je u značajnoj vezi samo sa paranoidnošću. Dimenzija Netolerancija nepredvidivosti ostvaruje značajnu vezu samo sa anksioznošću. Preostale dimenzije Odlučnost $i$ Otvorenost/Fleksibilnost su u vezi sa paranoidnošću jedino kada se anksioznost ne drži pod kontrolom, iz čega je pretpostavljena medijaciona uloga anksioznosti u relaciji ovih NFC dimenzija i paranoidnosti. Medijacija je potvrdena serijom regresija i Sobelovim testom. Rezultati su diskutovani u svetlu savremenih kognitivnih teorija paranoidnosti i anksioznosti.

Ključne reči: potreba za zaokruženošću, paranoidnost, anksioznost

1 Rad je rezultat projekta (\#149088) «Psihološke karakteristike društva u tranziciji» koji finansira Republičko ministarstvo nauke republike Srbije.

2 dragana.gogic@gmail.com 


\section{Uvod}

Prema savremenim kognitivnim teorijama sumanutih ideja i paranoidnosti značajnu kauzalnu ulogu u njihovom nastanku ima koncept potrebe za zaokruženošću (Bentall \& Swarbrick, 2003; McKay, Langdon, \& Coltheart, 2007). Definisan kao preferencija bilo kog odgovora na datu temu nasuprot daljem trajanju neodređenosti i neizvesnosti situacije, ovaj koncept smatra se odgovornim za brzopletu, pogrešnu i sumanutu interpretaciju realnosti od strane paranoidnih osoba. Potreba za zaokruženošću kao višedimenzionalan konstrukt u sebe uključuje: Neugodnost u situaciji neodređenosti, Žudnju za predvidljivošću, Preferenciju reda i strukture, Odlučnost i Rigidnost (Webster \& Kruglanski, 1994). Nalazi dobijeni na nekliničkoj populaciji ukazali su da osobe sklone sumanutostima pokazuju i sklonost ka skakanju na zaključak i visoku potrebu za zaokruženošću (Colbert \& Peters, 2002). U nekim slučajevima potreba za zaokruženošću jeste bila u vezi sa paranoidnim poremećajem, ali ne i sa skakanjem na zaključke (McKay, Langdon, \& Coltheart, 2007).

Brojna su istraživanja koja ističu važnost anksioznosti kao predispozicionog faktora za paranoidna stanja i poremećaje (Freeman et al., 2003; Freeman et al., 2005a). Smatra se da anksioznost igra značajnu ulogu u kreiranju paranoidnih misli (Freeman et al. 2005a; Martin \& Penn, 2001) i da procesi koji su u vezi sa anksioznošću učestvuju u distresu i održavanju persekutornih sumanutosti (Freeman, Garety, Kuipers, Fowler, \& Bebbington, 2002; Naeem, Kingdon, \& Turkington, 2006). Na nekliničkom uzorku pokazalo se da paranoidne misli nastaju iz uobičajenih interpersonalnih briga i anksioznosti (Freeman et al., 2005; Freeman et al., 2003; Freeman et al., 2005b).

Savremene kognitivne teorije anksioznih poremećaja navode konstrukt netolerancije neizvesnosti bitnim činiocem vulnerabilnosti za razvoj anksioznosti i anksioznih poremećaja (Dugas, Buhr, \& Ladouceur, 2004). Netolerancija neizvesnosti može biti definisana kao tendencija da se na neizvesne situacije ili događaje reaguje negativno na emotivnom, kognitivnom i bihejvioralnom nivou (Dugas et al., 2004). Osobe koje su netolerantne na neizvesnost smatraju da je neizvesnost stresna i uznemiravajuća, veruju da je neizvesnost negativna i da treba biti izbegnuta, i imaju poteškoća u funkcionisanju u neizvesnoj situaciji (Buhr \& Dugas, 2002).

Teško je ne uvideti sličnost između konstrukata potrebe za zaokruženošću i netolerancije neizvesnosti te veze između ovih predispozicionih karakteristika sugerišu još jedan temelj za istraživanje veze između paranoidnosti i anksioznosti. Otuda je cilj ovog rada da se utvrdi veza potrebe za zaokruženošću sa anksioznošću i sa paranoidnošću. Tačnije, namera ovog istraživanja je da se 
utvrdi uloga anksioznosti u relaciji između paranoidnosti i pojedinačnih dimenzija potrebe za zaokruženošću.

\section{Metod}

\section{Uzorak i postupak}

U istraživanju je učestvovalo 170 studenata Novosadskog univerziteta, u periodu od maja do juna meseca 2009 godine. Uzorak su činili 101 osoba muškog, i 69 ženskog pola, prosečne starosti od 21 godinu. $\mathrm{Na}$ osnovu prosečnog skora na Skali paranoidnosti, ispitanici su podeljeni u grupu visoko paranoidnih $(\mathrm{N}=75)$ i nisko paranoidnih $(\mathrm{N}=95)$.

\section{Instrumenti}

NFCS. (Need For Closure Scale, Webster \& Kruglanski, 1994) je skala koja meri individualne razlike u potrebi za zaokruženošću. Sastoji se od 47 ajtema na koje se odgovara na šestostepenoj skali. Upitnik je višedimen-zionalan i sadrži pet dimenzija: Red (eng. Order), Izvesnost (eng. Predicta-bility), Odlučnost (eng. Decisiveness), Neodredenost (eng. Ambiguity), Rigid-nost (eng. Closed Mindedness). Skala sadrži i skalu laganja, te se ajtemi ove skale ne uzimaju u obzir prilikom merenja postignutog skora na dimenzijama potrebe za zaokruženošću.

Analizom glavnih komponenti na našem uzorku takođe je, na osnovu Scree testa izdvojeno pet dimenzija potrebe za zaokruženošću, koje zajedno objašnjavaju 40\% varijanse. Dimenzije su dovedene u Varimax poziciju. Izolovane su dimenzije: Netolerancija nepredvidivosti ("Ne volim da sam sa ljudima koji su sposobni za nepredviđena dela"), Potreba za redom i strukturom ("Volim da za svaku stvar imam plan i mesto"), Potreba za kontrolom i rutinom ("Osećam se neprijatno kada ne znam šta neko misli ili namerava"), Odlučnost ("Važne odluke obično donosim brzo i samopouzdano") i Otvorenost za drugačija mišljenja/Fleksibilnost ("Uvažavam što više mogućih različitih mišljenja u vezi sa problemom o kom razmišljam”).

Pouzdanost skale NFCS na našem uzorku je bila Cronbach $\alpha=0,68$.

PS. (Fenigstein Paranoia Scale, Fenigstein \& Vanable, 1992) je samo-opisna skala nastala odabirom ajtema iz Pa skale MMPI-a. Koristi se kao opšta mera paranoidnosti na nekliničkoj populaciji. Sadrži 20 tvrdnji, na koje se odgovara pomoću petostepene Likertove skale. Uključuje ajteme koji se odnose na ideje 
persekucije i na ideje referencije. Mogući postignut skor se kreće od 20 do 100, gde najviši skor podrazumeva najvišu paranoidnu ideaciju. U ovom istraživanju skala PS pokazala je visoku pouzdanost, vrednost Cronbachove $\alpha$ iznosi 0,88 .

STAI-T. (State- Trait Anxiety Inventory, Spielberger et al., 1970), odnosno STAI-T (trait anxiety), forma instrumenta koja meri pokazatelje anksioznosti kao relativno stabilne osobine ličnosti. Primenjena forma upitnika sadrži 20 tvrdnji koje reprezentuju simptome ili karakteristike anksioznosti, a na koje su odgovori ponuđeni u vidu četvorostepene skale. Sudeći prema vrednosti Cronbachove $\alpha$ koja iznosi 0,89 , pouzdanost STAI-T skale je visoka.

\section{Rezultati}

\section{Odnos paranoidnosti i potrebe za zaokruženošću}

Da bi se rasvetlila veza između potrebe za zaokruženošću i paranoidnosti, izvršena je MANOVA. Paranoidnost (grupa sa visokim i niskim skorom na PS) je predstavljala nezavisnu, a dimenzije potrebe za zaokruženošću zavisne varijable. Multivarijatni testovi značajnosti ukazuju na značajnost celokupnog modela $[\mathrm{F}(5,164)=7,49, \mathrm{p}=0,001]$.

Tabela 1. Univarijatni rezultati za svaku zavisnu varijablu

\begin{tabular}{|c|c|c|c|c|c|c|c|c|c|c|c|}
\hline & \multirow[t]{2}{*}{$d f$} & \multicolumn{2}{|c|}{ Nepredvidivost } & \multicolumn{2}{|c|}{$\begin{array}{l}\text { Red i } \\
\text { struktura }\end{array}$} & \multicolumn{2}{|c|}{$\begin{array}{l}\text { Kontrola } \\
\text { i rutina }\end{array}$} & \multicolumn{2}{|c|}{ Odlučnost } & \multicolumn{2}{|c|}{$\begin{array}{l}\text { Otvorenost/ } \\
\text { Fleksibilnost }\end{array}$} \\
\hline & & $F$ & $p$ & $F$ & $p$ & $F$ & $p$ & $F$ & $p$ & $F$ & $p$ \\
\hline Paranoidnost & 1 & .00 & .96 & 1.23 & .27 & 20.02 & .00 & 7.36 & .01 & 5.23 & .02 \\
\hline Error & 168 & & & & & & & & & & \\
\hline Total & 169 & & & & & & & & & & \\
\hline
\end{tabular}

Rezultati prikazani u Tabeli 1., sugerišu da se paranoidni i neparanoidni subjekti značajno razlikuju na dimenzijama Potreba za kontrolom i rutinom, Odlučnost i Otvorenost /Fleksibilnost. 
Wilks lambda $=, 81405, F(5,164)=7,4925, p=, 00000$

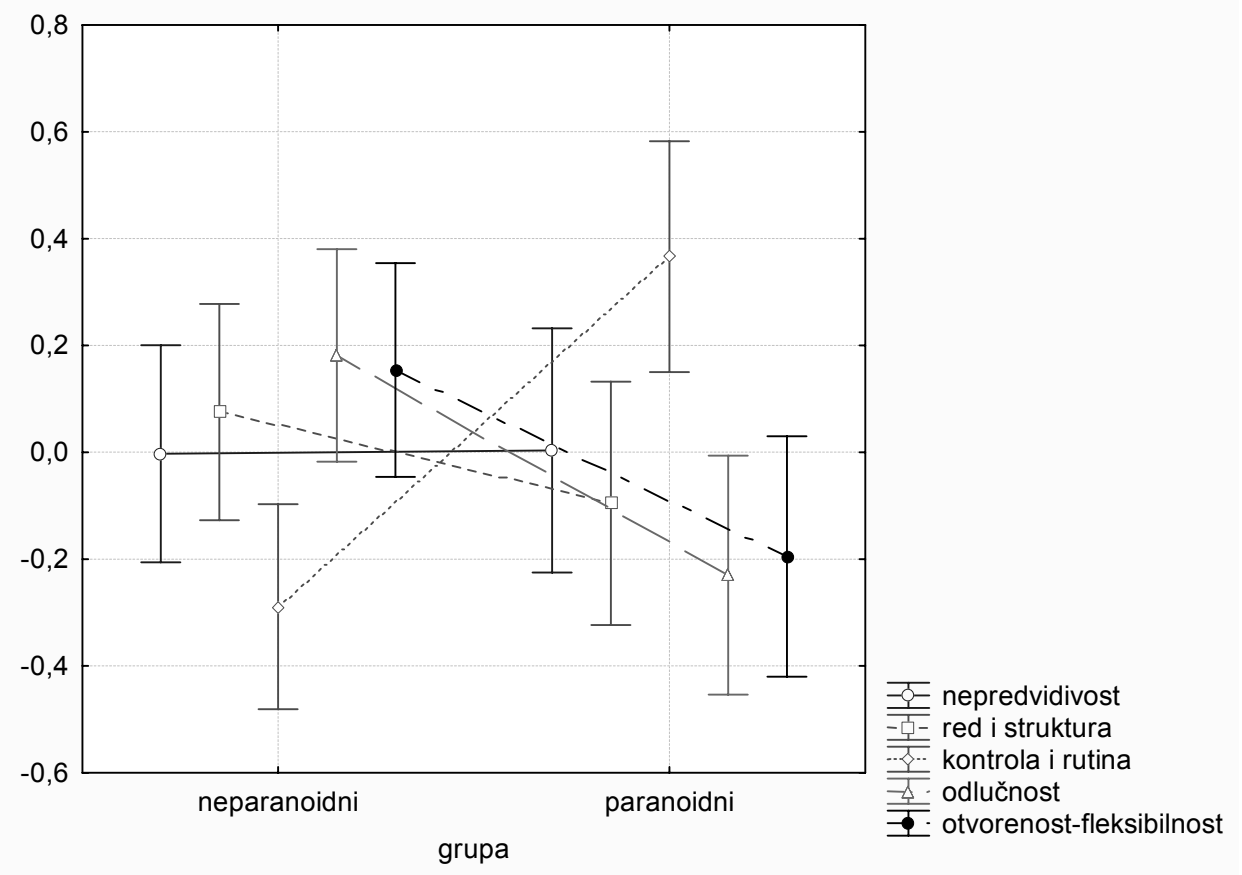

Grafikon 1. Prosečni skorovi paranoidnih i neparanoidnih ispitanika na dimenzijama potrebe za zaokruženošću

U analizu je uvedena MANCOVA sa ciljem da se ustanovi odnos paranoidnosti i potrebe za zaokruženošću, pod uslovom da se anksioznost drži pod kontrolom. Skorovi na STAI-T su tako uvedeni kao kovarijat, dok su dimenzije NFCS ponovo zavisne varijable, a paranoidnost nezavisna kategorijalna. Multivarijatni testovi značajnosti ukazuju na značajan efekat i paranoidnosti $[\mathrm{F}(5,163)=3.59, \mathrm{p}=.004]$ i anksioznosti $[\mathrm{F}(5,163)=20.23$, $\mathrm{p}=.000$ ]. Univarijatni testovi (Tabela 2.) ukazuju na to da su Odlučnost i Otvorenost/Fleksibilnost sada zančajno povezani sa anksioznošću, dok jedino dimenzija Potreba za kontrolom i rutinom ostvaruje značajnu vezu sa paraoidnošću. Netolerancija nepredvidivost je u vezi samo sa anksioznošću. 
Dragana Gogić, Veljko Jovanović, Zdenka Novović

Tabela 2. Univarijatni rezultati za svaku zavisnu varijablu

\begin{tabular}{l|lllllllllll}
\hline & df & \multicolumn{1}{l}{ Nepredidi-vost } & \multicolumn{2}{l}{$\begin{array}{l}\text { Red i } \\
\text { struktura }\end{array}$} & \multicolumn{3}{c}{$\begin{array}{l}\text { Kontrola } \\
\text { i rutina }\end{array}$} & Odlučnost & \multicolumn{2}{l}{$\begin{array}{l}\text { Otvorenost/ } \\
\text { Fleksibilnost }\end{array}$} \\
\hline & & $F$ & $p$ & $F$ & $p$ & $F$ & $p$ & $F$ & $p$ & $F$ & $p$ \\
Anksioznost & 1 & 19.47 & .00 & .00 & .94 & 2.72 & .10 & 44.47 & .00 & 5.36 & .02 \\
Paranoidnost & 1 & 2.84 & .09 & .97 & .32 & 12.21 & .00 & .04 & .85 & 1.51 & .22 \\
Error & 167 & & & & & & & & & & \\
Total & 169 & & & & & & & & & & \\
\hline
\end{tabular}

$\mathrm{Na}$ osnovu ovih rezultata ustanovili smo da jedna od dimenzija NFC nema uopšte veze niti sa anksioznošću niti sa paranoidnošću (Potreba za redom i strukturom), po jedna dimenzija je u direktnoj vezi samo sa anksioznošću (Netolerancija neprevidivosti) ili paranoidnošću (Potreba za kontrolom i rutinom). Preostale dve dimenzije su ostvarile vezu sa paranoidnošću, ali se ova veza izgubila kada smo anksioznost držali pod kontrolom. Pretpostavili smo da bi u slučaju ove dve dimenzije potrebe za zaokruženoću, anksioznost mogla imati ulogu medijatora. Otuda smo proverili medijaciju serijom regresija prema uputstvima Baron-a i Kenny-a (Baron \& Kenny, 1986). Odnos između dimenzija NFC, paranoidnosti i anksioznosti, koji smo pretpostavili na osnovu dosadašnjih analiza predstavljeni su na Slici 1.

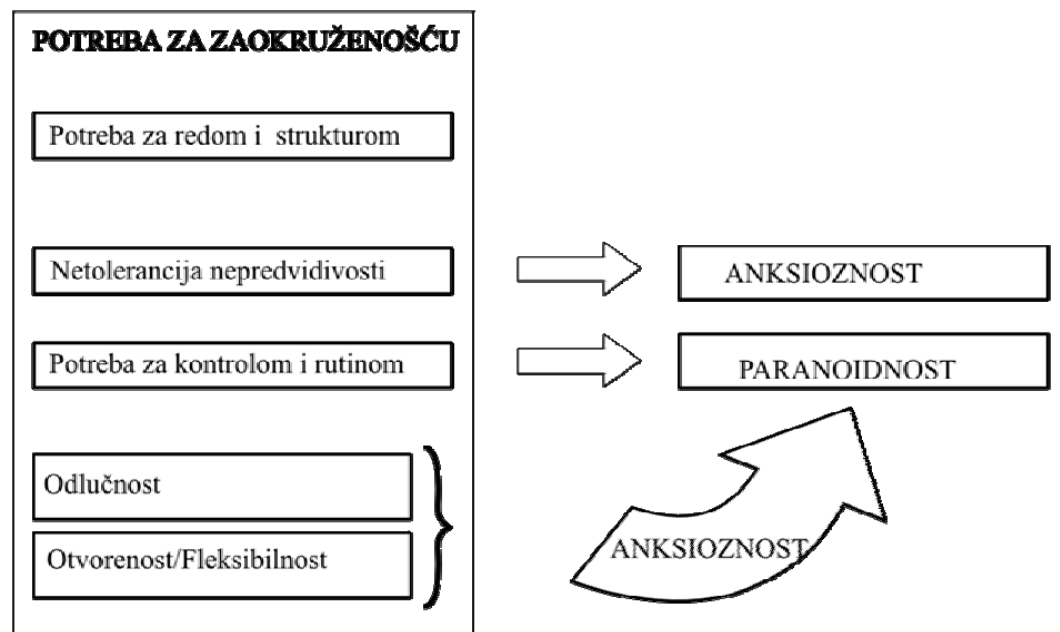

Slika 1. Odnos dimenzija potrebe za zaokruženošću, paranoidnosti i anksioznosti 


\section{Provera medijacije anksioznosti u relaciji NFC dimenzije Odlučnost i paranoidnosti}

Baron i Kenny (1986) predlažu sledeće korake u proveri medijacije koje smo proverili:

a)Nezavisna varijabla predvida medijator varijablu

Odlučnost je značajan prediktor anksioznosti: $B=-4,64 ;$ Std.gr=0,63; p=0,001).

b) Nezavisna varijabla predviđa zavisnu varijablu

Odlučnost značajno predviđa paranoidnost: $B=-2,87 ;$ Std.gr. $=1,05 ; p=0,006$

c) U regresiji u kojoj su prediktori medijator i nezavisna varijabla, medijator predviđa zavisnu varijablu

Anksioznost značajno predviđa paranoidnost, u regresionoj analizi u kojoj su anksioznost i Odlučnost prediktori, a paranoidnost kriterijum: koeficijent za STAI-T je B=0,66, Std.gr. $=0,11 ; p=0,000$, a za Odlučnost $B=0,20$, Std.gr=1,11; $\mathrm{p}=0,85$. Pošto se veza između NFC dimenzije Odlučnost i paranoidnosti gubi, a veza sa anksioznošću ostaje značajna, zaključujemo o tome da se verovatno radi o potpunoj medijaciji.

$\mathrm{Na}$ osnovu vrednosti iz gornjih regresija izračunat je Sobelov test medijacije=5,99; $\mathrm{p}=0,001$ (twotailed).

d) Provera recipročnog puta - zavisna varijabla ne utiče na medijator varijablu, odnosno model u kome je zavisna varijabla medijator, a medijator zavisna nije značajan.

Ovaj uslov nije potvrđen jer se u regresionoj analizi u kojoj je anksioznost kriterijum, a paranoidnost prediktor dobija da paranoidnost značajno predviđa (utiče na) anksioznost: $B=0,30$, Std.gr. $=0,05 ; p=0,000$; Sobelov test $u$ kome je paranoidnost medijator anksioznosti je takođe značajan (2,73, $\mathrm{p}=0,006$ (twotailed)), što sugeriše mogućnost da je dimenzija NFC-Odlučnost činilac razvoja anksioznosti dok paranoidnost igra medijacionu ulogu.

\section{Provera medijacije anksioznosti u relaciji NFC dimenzije} Otvorenost/Fleksibilnost i paranoidnosti

a) Nezavisna varijabla predviđa medijator varijablu

Otvorenost/Fleksibilnost je značajan (negativni) prediktor anksioznosti [F(1, 168) $=9,1986 \mathrm{p}<0,003$. $\mathrm{B}=-2,15 ;$ Std.gr. $=0,71 ; \mathrm{p}=0,002)]$. 
b) Nezavisna varijabla predviđa zavisnu varijablu

Otvorenost/Fleksibilnost je značajan (negativan) prediktor paranoidnosti, $[\mathrm{F}(1,168)=8.1536 \mathrm{p}=0,005, \mathrm{~B}=-2,98$, Std. gr. $=1,04 ; \mathrm{p}=0,004]$.

c) U regresiji u kojoj su prediktori medijator i nezavisna varijabla, medijator predviđa zavisnu varijablu

Anksioznost značajno predviđa paranoidnost, u regresionoj analizi u kojoj su anksioznost i Odlučnost prediktori, a paranoidnost kriterijum $[\mathrm{F}(2,167)=22,172$, $p=0,001$. Nestandardizovani koeficijent $B=0,61$, Std.gr. $=0,10, p=0,001$, za STAI-T, a za Otvorenost/Fleksibilnost $B=1,67$, Std.gr. $=0,98, p=0,09$. Sobelov test medijacije $=2,71 \mathrm{p}=0,006$ (twotailed).

d) Provera recipročnog puta - zavisna varijabla ne utiče na medijator varijablu, odnosno model u kome je zavisna varijabla medijator, a medijator zavisna nije značajan.

Ovaj uslov nije potvrđen jer se u regresionoj analizi u kojoj je anksioznost kriterijum, a paranoidnost prediktor dobija da paranoidnost značajno predviđa (utiče na) anksioznost: $B=0,30$, Std.gr. $=0,05, p=0,001$; Sobel $=2,15$, $\mathrm{p}=0,006$ (twotailed).

\section{Diskusija}

Ideja za ovaj rad proistekla je iz dva relativno nezavisna teorijska i empirijska izvora-prvi je kognitivna teorija psihotičnih fenomena, konkretnije paranoidnih sumanutosti, a druga teorija anksioznih poremećaja. Nezavisnost ove dve kognitivističke struje rezultovala je i konceptualnom nezavisnošću dva relativno srodna fenomena koji se, prema našim rezultatima, bar delom preklapaju. Tako je potreba za zaokruženošću postala bitan činilac razvoja paranoidnih sumanutosti u teorijskim postavkama engleskih teoretičara psihoza (Bentall \& Swarbrick, 2003), a netolerancija neizvesnosti karakteristika osoba predisponiranih za razvoj anksioznih poremećaja, prvenstveno generalizovanog anksioznog poremećaja (Ladouceur, Gosselin \& Dugas, 2000). Pored sličnosti i/ili preklapanja, koju smo naslutili između potrebe za zaokruženošću i netolerancije neizvesnosti, neki autori kognitivnih teorija psihoza ukazuju na značaj anksioznosti u razvoju paranoidnih sumanutosti (Freeman et al., 2005). Sve ovo nas je navelo da ispitamo relaciju između potrebe za zaokruženošću, paranoidnosti i anksioznosti.

Pošto smo faktorisali poznati instrument za merenje potrebe zaokruženošću, ustanovili smo, slično njegovom autoru i istraživačima koji su se bavili 
strukturom ovog fenomena (Webster \& Kruglanski, 1994; Mannetti, Pierro, Kruglanski, Tari \& Bezinovic, 2002), da je ova potreba višedimenzionalna. Dobijeni faktori su identifikovani takođe slično stranim istraživačima kao: Netolerancija nepredvidivosti, Potreba za redom i strukturom, Potreba za kontrolom i rutinom, Odlučnost i Otvorenost/Fleksibilnost.

Pretpostavili smo da se ove pojedinačne facete različito odnose prema paranoidnosti i anksioznosti, kao i da anksioznost može imati različitu ulogu u relaciji pojedinih dimenzija potrebe za zaokruženošću i paranoidnosti, i naši rezultati su zaista ukazali na ovakvu heterogenu strukturu povezanosti. Pogledajmo kako se svaka od dimenzija NFC pokazala u našim analizama.

Pre svega, jedna od dimenzija, Potreba za redom $i$ strukturom ni u jednoj analizi nije bila povezana, niti sa paranoidnošću, niti sa anksioznošću. Nepovezanost ove dimenzije NFC sa anksioznošću je shvatljiva i u nekliničkim uslovima kakvi su bili u našem istraživanju, a i ako želimo da ovaj rezultat ekstrapoliramo na kliničku populaciju. Jasno je da nekim osobama upravo neorganizovan, nestrukturisan život može biti uzrok povišene anksioznosti, dok drugima planiranje, organizacija i urednost mogu biti „lek“ protiv anksioznosti. Kad su u pitanju kliničke grupe u kojima je anksioznost jedan od bitnih simptoma (anksiozno-fobični poremećaji), najizraženiju potrebu za redom viđamo kod opsesivnih pacijenata, dok kod ostalih ova karakteristika ne mora biti naglašena. U meri u kojoj perfekcionističke sklonosti i potreba za kontrolom mogu biti značajni generatori neurotskih simptoma, potreba za redom kao jedan, ali ne i jedini način ispoljavanja ovih težnji, bi mogla biti u vezi sa (anksioznim) simptomima. Ipak, druge motivacione sile mogu biti presudnije (npr. pasivno receptivne) te se i u kliničkim uslovima jasno sagledava nepostojanje veze ove NFC dimenzije i anksioznosti.

Teže je objasniti nepovezanost paranoidnosti sa Potrebom za redom i strukturom. Moguće je da nam se ova veza činila verovatnom zbog toga što „klinička“ paranoidnost najčešće podrazumeva kompulzivnu, dogmatsku rigidnost u koju se lako uklapa i potreba za redom, planiranjem, organizovanošću, kao i zbog zdravorazumske pretpostavke da osobe koje imaju pojačanu interpretativnu spremnost pojačanim redom lakše kontrolišu sredinu. U istraživanju Leone, Wallace \& Modglin (1999) NFCS i Skala lične potrebe za strukturom (Neuberg \& Newson, 1993) su bile visoko povezane - autori čak ukazuju na deo ajtema u obe skale koji meri isti fenomen, upravo onaj deo koji se tiče Potrebe za redom i strukturom u NFCS. U istom istraživanju, međutim, Skala lične potrebe za strukturom nije bila intenzivnije povezana sa skalom dogmatizma, što bi objašnjavalo bar delom i naše rezultate koji se tiču nepovezanosti dimenzije Potrebe za redom i strukturom sa paranoidnošću, 
pogotovo ako je shvatimo na već navedeni način i vežemo za kliničku populaciju.

Dimenzija Netolerancija nepredvidivosti se pokazala povezanom samo sa anksioznošću. Ova je veza sasvim očekivana, a dimenzija Netoleranija nepredvidivosti je po sadržaju najbliskija pominjanoj netoleranciji neizvesnosti koja se u novijim teorijama razvoja generalizovanog anksioznog poremećaja pominje kao značajna predisponirajuća karakteristika (Ladouceur, Gosselin, \& Dugas, 2000). Naši rezultati sugerišu da sličnost konstrukata potrebe za zaokruženošću i netolerancije neizvesnosti počiva na jednoj subdimenziji NFC, te da je ova dimenzija zaista jedinstveno povezana sa anksioznošću, a ne i sa paranoidnošću. Ostaje međutim značajno pitanje u kojoj meri je ova dimenzija zaista aspekt potrebe za zaokruženošću- želje individue da relativno brzo stigne do zatvaranja u odlučivanju i prosuđivanju. NFCS je zamišljen kao jednodimenzionalan instrument koji treba da meri jedinstveni konstrukt preko pet različitih načina na koje se ispoljava (Webster \& Kruglanski, 1994). Jednodimenzionalnost i/ili dvodimenzionalnost instrumenta je potvrđena na više različitih uzoraka u svetu (Mannetti, Piero, Kruglanski, Taris, \& Bezinovic, 2002; Kossowska, Van Hiel, Chun, \& Kruglanski, 2002) i SAD (Kruglanski, DeGrada, Mannetti, Atash, \& Webster, 1997), pri čemu se u dvodimenzionalnom rešenju Odlučnost izdvaja od ostalih aspekata NFC koji zajedno čine Potrebu za jednostavnom strukturom. Različite veze koje, u našem istraživanju, pojedini načini ispoljavanja NFC, ostvaruju sa drugim konstruktima, kao npr. Netolerancija nepredvidivosti sa anksioznošću ili Potreba za kontrolom i rutinom sa paranoidnošću, sugerišu ipak višedimenzionalnost NFC, i to ne onakvu kakvu su faktorska istraživanja ovog konstrukta dokazivala. Ovo ukazuje na potrebu preispitivanja konstrukt validnosti NFC, ne samo kroz istraživanja njegove unutrašnje strukture, već i relacije sa različitim spoljašnjim kriterijumima.

Sledeća dimenzija NFC - Potreba za kontrolom i rutinom u vezi je isključivo sa paranoidnošću i ova veza ostaje značajna kada se anksioznost drži pod kontrolom. Ajtemi koji su tipični za ovu dimenziju ukazuju na potrebu da se zna zašto se bilo šta dešava, kao i na potrebu da se poznaju tuđe misli i namere. Rutiniziran život jedino omogućava da se uživa u životu, jer se jedino tako ima osećaj kontrole nad životom. Budući da se jedino ovaj aspekt NFC pokazuje specifično povezanim sa paranoidnošću, moguće je da je nediferenciranje ove dimenzije u ranijim istraživanjima uzrok nekonzistentnih rezultata o odnosu NFC i paranoidnosti. Ajtemi koji ulaze u sastav ovog faktora delom se nalaze u okviru subskale Netolerancije nejasnoće, koja se pokazala u jednom istraživanju značajnim prediktorom paranoidnosti (Freeman et al., 2005). 
Ipak $u$ većini istraživanja, korišćena je dvodimenzionalna verzija upitnika $u$ kojoj su ajtemi Potrebe za kontrolom posmatrani zajedno sa ostalim ajtemima dimenzije Potreba za jednostavnom strukturom. Moguće da su upravo stavke koje se tiču mogućnosti kontrole ljudskih namera i mišljenja u najvećoj vezi sa paranoidnošću pošto u najvećoj meri dotiču strahove i potrebe paranoika, te da bi skala, koja bi se u većoj meri odnosila na potrebu za kontrolom, predviđanjem i strukturisanošću u interpersonalnim situacijama, zaista pokrivala specifičnu potrebu za zaokruženošću paranoidnih osoba.

Odlučnost je dimenzija NFC za koju je ustanovljeno da možda imaju efekat na paranoidnost preko anksioznosti. Drugim rečima, anksioznost bi mogla imati medijatornu ulogu u razvoju paranoidnosti kod osoba sa povišenom (ne)odlučnošću. Odlučnost je aspekt NFC koncepta Kruglanskog najbitnija dimenzija jer se odnosi upravo na potrebu za brzim donošenjem zaključaka i odluka usled netolerancije neodređenosti, nepredvidivosti i nejasnoće. Odlučnost se, međutim, u našem istraživanju pokazala negativno povezanom kako sa anksioznošću tako i paranoidnošću. Negativna veza sa anksioznošću je očekivana, ali je sa paranoidnošću trebalo da bude pozitivna u skladu sa pretpostavkom o "skakanju na zaključke“ kao tipičnom paranoidnom kognitivnom pristrasnošću. Otuda je pitanje da li, kada govorimo o Odlučnosti, govorimo zaista o još jednom aspektu potrebe za zaokruženosti ili nezavisnoj karakteristici ličnosti koja ima veze sa paranoidnošću. Neodlučnost nije aspekt potrebe za zaokruženošću. Vrlo slični rezultati su dobijeni i u istraživanju Freeman- a, Garety i sar, (2006). Snižena odlučnost je bila u vezi sa psihotičnim simptomima, a takođe je značajnija veza dobijena sa afektom anksioznošću i depresivnošću. Medijaciona analiza u našem istraživanju potvrdila je mogućnost da anksioznost bude medijator u razvoju paranoidnosti - pojačana neodlučnost vodi pojačanoj anksioznosti zbog npr. Produžavanja neizvesne situacije, da bi na kraju dovela do senzitivnih interpretacija $u$ smislu prenošenja krivice za sopstvenu situaciju na druge ili u smislu referentnih ideja - osećaja da im se drugi ljudi podsmevaju i rugaju zbog situacije u kojoj se nalaze. Medijaciona analiza ukazala je, međutim i na mogućnost da paranoidnost predviđa anksioznost, što bi moglo biti objašnjenje za produžavanje hipersenzitivnih reakcija u situacijama stresa, kada povratna sprega između anksioznosti i paranoidnosti može produžavati stanje sumnjičavosti, osetljivosti i interpretativne spremnosti, a na temelju neodlučne, amivalentne bazične strukture ličnosti.

Niska Otvorenost/Fleksibilnost je ostvarila isti sklop veza sa paranoidnošću i anksioznošću i takođe postoji mogućnost da anksioznost igra ulogu medijaora u razvoju paranoidne ideacije na temelju strukture ličnosti kod koje je 
naglašena nefleksibilnost, odnosno zatvorenost za drugačija mišljenja. Ovakva netolerancija u interpersonalnim relacijama svakako je činilac problematičnog socijalnog funkcionisanja generalno i odbacivanja osobe od strane društva, što jeste dobar osnov za anksioznost u ovakvim situacijama, koja bi potom vodila paranoidnim obradama tih situacija. I ovde je međutim moguć i obrnut put kauzalnosti sugerišući da bi paranoidne obrade mogle voditi anksioznosti, te bismo i ovde mogli očekivati „začarani krug“ koji osobu održava u paraoidnom stanju.

Budući da je u pitanju korelativni nacrt, kao i da je uzorak neklinički, ovakve nalaze moramo prihvatiti sa rezervom i eventualno ih smatrati dobrim ralogom za dalja i validnija istraživanja ovih fenomena. Najvažniji nalaz, da raličiti aspekti NFC mogu biti u različitim relacijama sa (nekliničkom) paraoidnošću, te da anksioznost može imati različitu ulogu u ovim relacijama, je ipak nesporan.

\section{Zaključci}

1. Potreba za zaokruženošću je višedimenzionalan konstrukt. Srpski prevod instrumenta za merenje NFC faktorizacijom daje dimenzije slične aspekima NFC koje sugeriše autor.

2. Jedna od dimenzija NFC - Netolerancija nepredvidivosti - najverovatnije se preklapa sa Netolerancijom neizvesnosti (predispozicijom za razvoj anksioznih poremećaja) i jedinstveno je povezana sa anksioznošću.

3. NFC dimenzija - Potreba za redom i strukturom nema veze niti sa anksioznošću niti sa paranoidnošću.

4. NFC dimenzije Odlučnost i Otvorenost/Fleksibilnost za drugačija mišljenja su u vezi sa paranoidnošću samo preko anksioznosti i moguće je da je anksioznost medijator preko koga se odvija razvoj senzitivnih interpretacija realnosti na temelju (snižene) odlučnosti i (ne)fleksibilnosti u interpersonalnoj komunikaciji.

5. NFC je heterogen konstrukt, čiji različiti aspekti ostvaruju specifične relacije sa različitim relevantnim fenomenima, te se postavlja pitanje da li se NFC (merena instrumentom Kruglanskog) zaista odnosi na jedinstven fenomen. 


\section{Literatura}

Baron, R.M., \& Kenny, D.A. (1986). The moderator-mediator variable distinction in social psychological research: Conceptual, strategic and statistical considerations. Journal of Personality and Social Psychology, 51, 1173-1182.

Bentall, R.P., \& Swarbrick, R. (2003). The best laid schemas of paranoid patients: Autonomy, sociotropy and need for closure. Psychology and Psychoterapy: Theory, Research and Practice, 76, 163-171.

Buhr, K., \& Dugas, M.J. (2002). The intolerance of uncertainty scale: psychometric properties of the English version. Behaviour Research and Therapy, 40, 931-945.

Colbert, S.M., \& Peters, E.R. (2002). Need for closure and jumping-toconclusions in delusion-prone individuals. Journal of Nervous and Mental Disease, 190, 27-31.

Dugas, M.J., Buhr, K., \& Ladouceur, R. (2004). The role of intolerance of uncertainty in etiology and maintenance. In: R.G. Heimberg, C.L. Turk and D.S. Mennin, (Eds.), Generalized anxiety disorder: Advances in research and practice, (pp. 143-163). New York: Guilford.

Fenigstein, A., \& Vanable, P.A. (1992). Paranoia and self-consciousness. Journal of Personality and Social Psychology, 62, 129-138.

Freeman, D., Dunn, G., Garety, P.A., Bebbington, P., Slater, M., Kuipers, E., Fowler, D., Green, C., Jordan, J., \& Ray, K. (2005). The psychology of persecutory ideation I: A questionnaire study. Journal of Nervous and Mental Disease, 193, 302-308.

Freeman, D., Garety, P.A., Bebbington, P.E., Slater, M., Kuipers, E., Fowler, D., Green, C., Jordan, J., Ray, K., \& Dunn, G. (2005a). The psychology of persecutory ideation II: A virtual reality experimental study. The Journal of Nervous and Mental Disease, 193, 309-315.

Freeman, D., Garety, P.A., Bebbington, P.E., Smith, B., Rollinson, R., Fowler, D., Kuipers, E., Ray, K., \& Dunn, G. (2005b). Psychological investigation of the structure of paranoia in a non-clinical population. British Journal of Psychiatry, 186, 427-435.

Freeman, D., Garety, P.A., Kuipers, E., Colbert, S., Jolley, S., Fowler, D., Dunn, G., \& Bebbington, P.E. (2006). Delusions and decision-making style: use 
of the Need for Closure Scale. Behaviour Research and Therapy, 44, 1147-1158.

Freeman, D., Garety, P.A., Kuipers, E., Fowler, D., \& Bebbington, P.E. (2002). A cognitive model of persecutory delusions. British Journal of Clinical Psychology, 41, 331-347.

Freeman, D., Slater, M., Bebbington, P.E., Garety, P.A., Kuipers, E., Fowler, D., Met, A., Read, C.M., Jordan, J., \& Vinayagamoorthy, V. (2003). Can virtual reality be used to investigate persecutory ideation? The Journal of Nervous and Mental Disease, 191, 509-514.

Kossowska, M., Van Hiel, A., Chun, W.Y., \& Kruglanski, A.W. (2002). The need for cognitive closure scale: Structure, cross-cultural invariance, and comparison of mean ratings between European American and East Asian samples. Psychologica Belgica, 42, 267-286.

Kruglanski, A.W., DeGrada, E., Mannetti, L., Atash, M.N., \& Webster, D.M. (1997). Psychological theory testing versus psychometric nay-saying: Comment on Neuberg et al.'s (1997) critique of the Need for Closure Scale. Journal of Personality and Social Psychology, 73, 1005-1016.

Ladouceur, R., Gosselin, P., \& Dugas, M.J. (2000). Experimental manipulation of intolerance of uncertainty: A study of a theoretical model of worry. Behaviour Research and Therapy, 38, 933-941.

Leone, C., Wallace, H.M., \& Modglin, K. (1999). The need for closure and the need for structure: Interrelationships, correlates and outcomes. Journal of Psychology, 133, 553-562.

Mannetti, L., Pierro, A., Kruglanski, A.W., Taris, T., \& Bezinovic, P. (2002). A cross cultural study of the need for cognitive closure scale: comparing its structure in Croatia, Italy, the USA and the Netherlands. British Journal of Social Psychology, 41, 139-156.

Martin, J.A., \& Penn, D.L. (2001). Brief report: Social cognition and subclinical paranoid ideation. British Journal of Clinical Psychology, 40, 261-265.

McKay, R., Langdon, R., \& Coltheart, M. (2007). Jumping to delusions? Paranoia, probabilistic reasoning, and need for closure. Cognitive Neuropsychiatry, 12, 362-376.

Naeem, F., Kingdon, D., Turkington, D. (2006). Cognitive behaviour therapy for schizophrenia: relationship between anxiety symptoms and therapy. Psychology E Psychotherapy: Theory, Research E Practice, 79, 153-164. 
Neuberg, S.L., \& Newsom, J.T. (1993). Personal Need for Structure: Individual differences in the desire for simple structure. Journal of Personality and Social Psychology, 65, 113-131.

Spielberger, C., Gorsuch, R., \& Luschene, R. (1970). Manual for the StateTrait Anxiety Inventory. Palo Alto, California: Consulting Psychologists Press.

Webster, D.M., \& Kruglanski, A.W. (1994). Individual need for cognitive closure. Journal of Personality and Social Psychology, 67, 1049-1062. 


\title{
Abstract \\ THE ROLE OF ANXIETY IN THE RELATIONSHIP BETWEEN NEED FOR CLOSURE AND PARANOID TENDENCIES
}

\author{
Dragana Gogić, Veljko Jovanović, Zdenka Novović
}

The aim of the study was to determine the role of anxiety in the relationship between paranoid tendencies and dimensions of Need for closure (NFC). NFCS - a measure of Need for closure, PS - paranoia scale and STAI-Tanxiety scale were administered to 170 students of Novi Sad University. The sample was divided into group with high $(\mathrm{N}=75)$ and low $(\mathrm{N}=95)$ paranoia tendencies on the basis of mean score on PS. Principal Component Analysis of NFCS produced five Varimax dimensions: Intolerance of Unpredictability, The Need for Order and Structure, The Need for control and routine, Decisiveness and Openness/flexibility. The relation of extracted NFC dimensions, with paranoid tendencies were tested through MANOVA and MANCOVA, while controlling anxiety as covariate. The Need for order and structure was not related to either paranoia, or anxiety, and Need for Control and Routine was related only to paranoid tendencies. The Decisiveness and Openness were related to paranoid tendencies only when anxiety had been controlled. The mediating role of anxiety was proposed, and confirmed through series of Regression analysis and Sobel's test. The results were discussed in the context of current cognitive theories of paranoia and anxiety.

Primljeno: 1. 12. 2009; prihvaćeno za štampu: 17. 12. 2009. 